\title{
Salt Marsh Plant Community Structure Influences Success of Avicennia germinans During Poleward Encroachment
}

\author{
Therese E. Adgie $^{1}$ (D) $\cdot$ Samantha K. Chapman ${ }^{1}$ \\ Received: 28 November 2020 / Accepted: 24 May 2021 / Published online: 10 August 2021 \\ (C) Society of Wetland Scientists 2021
}

\begin{abstract}
Along the Florida coast, decreasing freeze events are promoting the range shift of the mangrove species Avicennia germinans northward into temperate salt marsh wetlands. Although plant species' ranges are tightly linked with their climatic tolerances, there is considerable variability in the magnitude by which biotic factors like competition and facilitation may also influence range shifts. Changes in mangrove and marsh plant abundance can alter both the above and belowground environment, which may in turn influence ecosystem services typically associated with these systems such as storm surge abatement and carbon storage. Therefore, it is key to understand (1) how the above and belowground environment of established salt marshes influences establishment of mangroves, and (2) how above and belowground environments shift in response to mangrove encroachment. Using a semi-natural mangrove planting experiment, we investigated the impact of four distinct marsh plant community structures (Batis maritima, Spartina alterniflora, mixture of B. maritima and S. alterniflora, mudflat) on mangrove survivorship and decomposition rate. In mixed marsh plots, mangrove survivorship was $42 \%$ higher compared to survivorship in mudflat plots, and decomposition rate was $47 \%$ greater in mixed marsh plots compared to mudflat. However, percent cover of vegetation differed across treatments, and was highest in mixed marsh plots. High survivorship in mixed marsh plots is likely due to increased protection from physical stressors by the dense aboveground cover, and belowground plant root-driven effects such as nutrient availability and oxygen delivery. Our findings suggest that above and below ground differences in salt marsh plant community structure can have an impact on the survival of encroaching mangroves, which may have implications for predicting future mangrove encroachment and improving mangrove restoration techniques.
\end{abstract}

Keywords Batis maritima $\cdot$ Plant community $\cdot$ Facilitation $\cdot$ Mangrove encroachment

\section{Introduction}

Stressful conditions drive low species richness in coastal wetland plant communities, which in turn can result in more meaningful competitive and facilitative species interactions (Bertness and Hacker 1994; Emery et al. 2001; Ellison et al. 2005). Competitive interactions between salt marsh plants play an important role in determining species zonation patterns along the coast (Emery et al. 2001), and early colonization of stressful areas such as mud flats may promote

This article belongs to the Topical Collection: Coastal Wetlands.

Therese E. Adgie

Tadgie@ villanova.edu

1 Biology Department and Center for Biodiversity and Ecosystem Stewardship, Villanova University, Villanova, PA 19085, USA facilitation of different plant species (Milbrandt and Tinsley 2006). As the climate warms, many plant species ranges are shifting in response to sea-level rise and decreases in freezing stress, which impacts the plant community structure of coastal wetlands (Krauss et al. 2011, Saintilan et al. 2014; Cook-Patton et al. 2015). Shifts in foundation species in response to climate change are expected to have cascading effects on ecosystem structure and function (Osland et al. 2013). Though competition and facilitation are key drivers in structuring plant communities, it is largely unknown how these forces may influence the rate at which climate-change induced plant range shifts occur (HilleRisLambers et al. 2013).

Coastal wetland plant community structure is shifting as mangrove ranges are expanding poleward across the globe (Saintilan et al. 2014). In higher-latitude areas, mangroves are increasing in abundance and expanding into salt marshes and tidal flats within their established ranges, though the 
drivers of this "within-range" expansion are varied (Kelleway et al. 2016). In areas of Australia and New Zealand mangrove expansion is caused by increased rates of sedimentation due to changes in land use (Lovelock et al. 2007; Swales et al. 2015), and in some areas of South America landward expansion of mangroves is largely driven by sea-level rise (Godoy and Lacerda 2015). However, mangrove expansion in China is more complex due to extensive mangrove clearing, so the main driver of mangrove expansion remains unknown (Durango et al. 2013; Saintilan et al. 2014). At climate defined poleward limits, mangrove range expansion is predominately attributed to changing temperature thresholds resulting from climate change (Osland et al. 2013; Saintilan et al. 2014). Such is the case along the southeastern coast of the United States, where decreases in freeze events and their severity is driving the poleward shift of mangroves outside of their established range (Cavanaugh et al. 2014). Plant species ranges are tightly linked with their freeze tolerances, and the reduction in freeze events driven by warming temperatures in Louisiana, Texas, and Florida is promoting mangroves encroachment into salt marsh habitat (Perry and Mendelssohn 2009; Cavanaugh et al. 2014).

Though many freeze-sensitive species exhibit greater tolerance for freezing as they age, the black mangrove's freeze tolerance changes depending on its life stage. Black mangroves have three distinct early life stages; dispersal stage, stranded stage, and established seedling stage (Tomlinson 1986). In the dispersal stage, floating mangrove propagules can withstand fluctuating salinities, temperatures, and degrees of flooding (Rabinowitz 1978; Patterson et al. 1997; Delgado et al. 2001; Sousa et al. 2003). Once established, mangrove seedlings are more susceptible to freeze damage than propagules but become more resistant to freeze damage as they grow (Pickens and Hester 2011). Restoration projects have shown that in addition to size and life stage mangrove success may also be influenced by the presence of foundation species, which are species whose presence imparts a disproportionately large role in structuring ecosystems (Yando et al. 2019). However, it remains unclear how differences in plant community structure influences encroaching mangroves, especially at different life stages.

The stress-gradient hypothesis ( $\mathrm{SGH}$ ) predicts that while competition and facilitation co-occur, increased abiotic stressors correlates to increased facilitative interactions in plant communities (Bertness and Callaway 1994), though support for the SGH has depended on numerous factors including individual characteristics of the species involved (Malkinson and Tielbörger 2010; Casalini and Bisigato 2018). The rapid shift of salt marsh to mangrove occurring at the ecotone between these ecosystems provides a unique opportunity to study how competition and facilitation may occur dynamically depending on plant community and mangrove life stage (Risser 1995; Saintilan et al. 2014). Indeed, many salt marsh plant species have been implicated as both mangrove competitor and facilitator depending on context. In the tropics, the salt marsh succulent Batis maritima has been implicated as a potential facilitator of mangrove encroachment due to belowground interactions and dense growth habit (Milbrandt and Tinsley 2006; Whigham et al. 2009; TeutliHernández et al. 2019). Similarly, Spartina alterniflora may promote mangrove facilitation by providing shade and protection for establishing mangroves (Pickens et al. 2019), though S. alterniflora has also been implicated as a mangrove competitor due to allelopathic soil interactions (Chen et al. 2020). Adult mangroves can outcompete many marsh species for space and nutrients due to shading, superior reproduction, and belowground processes (Kangas and Lugo 1990), though restoration projects have indicated that prioritizing foundation marsh species health may promote initial mangrove establishment (Milbrandt and Tinsley 2006; Lewis 2009; Yando et al. 2016).

In addition to aboveground interactions, foundation marsh species can also directly modify aspects of their belowground environment (Rietl et al. 2016; Fujii et al. 2018). Soil environment modification can impact the fitness of plant species, potentially producing a reciprocal interaction commonly referred to as a plant-soil feedback (PSF; Kulmatiski et al. 2008; Allen et al. 2018). Though plant-soil feedback studies in wetlands are rare, plant-soil feedback loops can be particularly strong in areas with lower species richness (Corbin and D'Antonio 2012; Grove et al. 2015) such as coastal salt marshes. Salt marsh plant species can cultivate distinct soil microbial communities (Rietl et al. 2016) and can directly alter numerous abiotic factors in the soil. For example, B. maritima can sequester salt in its succulent-like leaves leading to upwards of $55 \%$ decrease in soil salinity compared to mudflats, and Batis has also been associated with increases in available soil nitrogen (Teutli-Hernandez et al. 2019). Spartina alterniflora has well developed aerenchyma that can leak oxygen into surrounding soils (Maricle and Lee 2002), which can result in soil oxidation, changes in soil redox, and changes in nutrient availability (Howes et al. 1986; Wigand et al. 1997; Perry and Mendhelsson 2009). Though B. maritima and S. alterniflora can directly alter belowground factors, it is not yet clear how these variations in soil environment across a marsh habitat may impact encroaching mangroves.

Mangroves also possess well-developed aerenchyma, and mangrove-associated soils tend to contain more aerobic bacteria than marsh soils (Barretto et al. 2018). This suggests that increases in mangrove abundance may drive the increase of heterotrophic respiration as mangroves encroach into salt marshes (Wolf et al. 2007; Kirwan and Blum 2011). Though biotic and abiotic factors that influence the belowground environment can be numerous, decomposition bags have been 
widely used as an integrated measurement of the belowground environment. This method provides a low-cost snapshot of the belowground environment as it relates to decomposition and labile carbon stabilization (Keuskamp et al. 2013; Mueller et al. 2018). Changes in mangrove and marsh plant abundance can both alter the belowground environment and associated ecosystem services, such as carbon storage (Comeaux et al. 2012; Doughty et al. 2016; Coldren et al. 2016; Barreto et al. 2018). Thus, it is key to understand (1) how the belowground environment of established salt marshes influences establishment of mangroves and (2) how belowground environment shifts in response to mangrove encroachment.

Using a site at the ecotone between where mangroves and salt marsh plants dominate in northeastern Florida, we have the unique opportunity to observe how variation in marsh plant community structure influences the success of establishing mangroves. We planted mangrove seedlings in plots with four different marsh plant community compositions, and thus can assess how plant community may impact mangroves' encroachment success at this key life stage. We measured mangrove seedling mortality and growth rates over 9 months and measured percent cover of the marsh plant cover to assess aboveground environment. We measured organic matter decomposition via the Tea Bag Index (TBI), which uses two types of tea to derive a decomposition rate $(\mathrm{k})$ reflecting initial decomposition, and a stabilization factor $(\mathrm{S})$ which reflects the fraction of labile organic matter that becomes stabilized during deployment (Keuskamp et al. 2013; Mueller et al. 2018; Seelen et al. 2019). We hypothesized that (1) mangroves planted in plots with greater percentages of $B$. maritima would exhibit lower mortality rates; (2) mangroves would exhibit low mortality in plots with greater plant percent cover; and (3) plots with planted mangroves would exhibit higher decomposition rates compared to paired plots without mangroves.

\section{Methods}

\section{Site Description}

This study was conducted at the Guana Tolomato Matanzas National Estuarine Research

Reserve (GTM), located just north of St. Augustine, Florida. GTM is 50 miles south of the northernmost known black mangrove in Florida $(30.11 \mathrm{~N}, 81.37 \mathrm{~W})$ and lies in the ecotone between salt marsh and mangroves (Cavanaugh et al. 2019). Mean elevation is $57 \mathrm{~cm}$, and mean salinity is $38.41 \mathrm{ppt}$ (Table 1). This site is dominated by a mixture of the salt marsh grass $S$. alterniflora, the marsh succulent $B$. maritima, and the mangrove species A. germinans.
Table 1 Site characteristics of Guana Tolomato Matanzas Research Reserve along the northeastern coast of Florida. Shown with permission from Chapman et al. 2021

\begin{tabular}{llll}
\hline Variable & \multicolumn{2}{l}{ GTM Site Characteristics } \\
\cline { 2 - 4 } & Mean & Range & SD \\
\hline Elevation $(\mathrm{cm})$ & 57 & $53-63$ & 3 \\
Longitude & $29^{\circ} 50^{\prime} 10.30^{\prime \prime} \mathrm{N}$ & & \\
Latitude & $81^{\circ} 17^{\prime} 42.25^{\prime \prime} \mathrm{W}$ & & \\
$\mathrm{pH}$ & $5.94-6.72$ & 4.68 & 0.53 \\
Redox $(\mathrm{mV})$ & 51.13 & $1-132$ & 33.82 \\
Soil temperature $(\mathrm{C})$ & 26.16 & $24.67-27.71$ & $\mathrm{NA}$ \\
Air temperature $\left({ }^{\circ} \mathrm{C}\right)$ & 16.44 & $0.47-30.76$ & 1.24 \\
Soil type & Histol/hydrosol & & \\
Bulk density $\left(\mathrm{g} / \mathrm{cm}^{\wedge} 3\right)$ & 0.69 & $0.33-0.90$ & 0.11 \\
Salinity $(\mathrm{ppt})$ & 38.41 & $32.00-43.00$ & 3.91 \\
\hline
\end{tabular}

\section{Experimental Design}

We established four distinct vegetation treatments that were selected based on the dominant plant community structures present across the low marsh; (1) S. alterniflora dominated, (2) B. maritima dominated, (3) mixture of S. alterniflora and B. maritima, and (4) mudflat with no vegetation (Fig. 1). Vegetation in each treatment had established naturally and required no further planting or clipping. Each treatment consisted of ten $1-\mathrm{m}^{2}$ plots, five of which were planted with 10 mangrove seedlings each, and five of which remained unplanted to serve as paired controls for the decomposition study. Survivorship and plant heights were measured in threemonth increments beginning in January 2019 at initial planting and concluding in November 2020.

\section{Mangrove Seedling Replanting}

Mangrove seedlings were wild collected across a roughly 10 $\mathrm{m}^{2}$ area at GTM with proper permissions from GTM managers. Approximately 200 mangroves between 1 and 3 years old and $20-40 \mathrm{~cm}$ in height were selected and removed, maintaining as much root biomass as possible. Over the course of two days, mangrove seedlings were selected at random, tagged, measured, photographed, and replanted in one of the 20 planted experimental plots.

\section{Mangrove Mortality}

After planting, we assessed mangrove survivorship success in three 3-month intervals. Once every 3 months, all tagged mangrove seedlings were counted as either living or dead. Seedlings were considered "living" if they still had green or yellowing leaves. Seedlings were counted as "dead" if they 


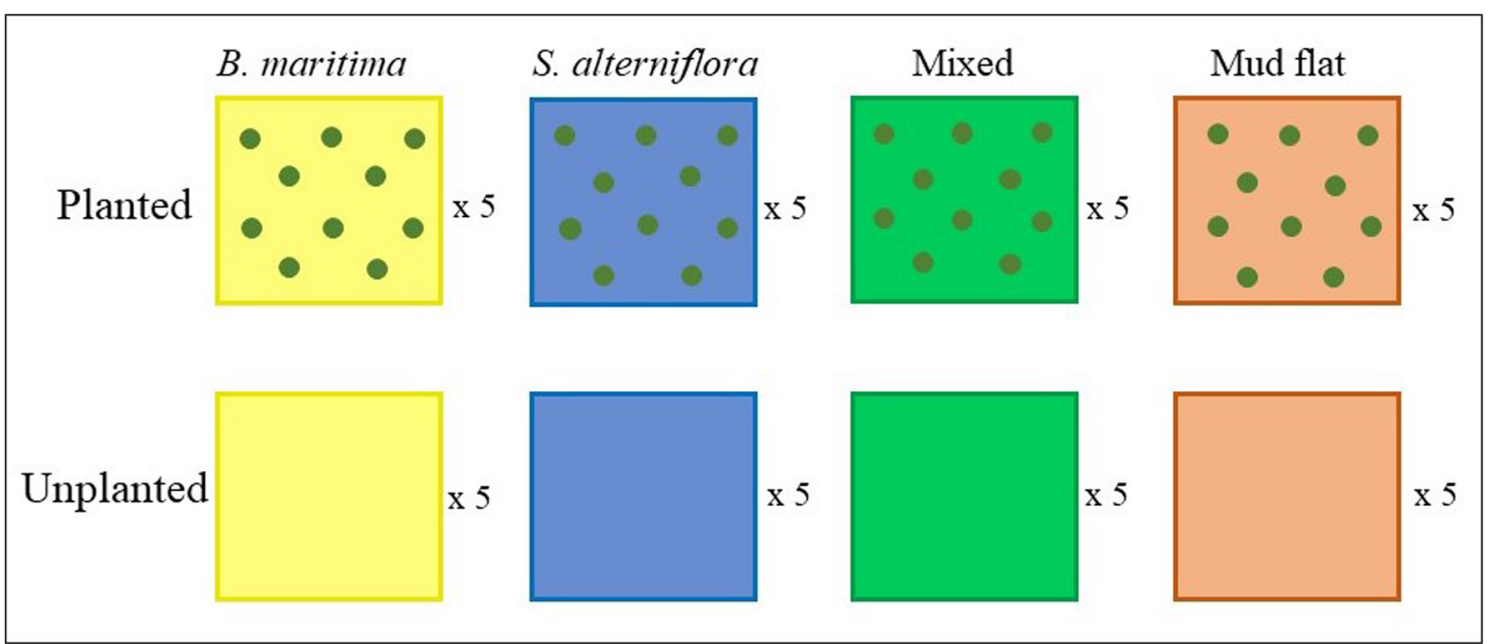

Fig. 1 Experiment design consisted of 40 plots separated into 4 treatments: (1) S. alterniflora dominated, (2) B. maritima dominated, (3) mixture of S. alterniflora and B. maritima, and (4) Mudflat with no

had no leaves and their stems were fragile and brittle. On two occasions, seedlings that were previously counted as dead resprouted live tissue at the base of their stems. Mortality was calculated by dividing the number of dead mangroves by ten and expressed as a percentage for each plot.

\section{Percent Cover Analysis}

During the last mortality measurement in November 2019, we photographed each of the experimental plots that contained vegetation (B. maritima, S. alterniflora, and Mixed). Photos were taken from approximately $1 \mathrm{~m}$ above each plot, aiming directly downward at the vegetation, and included all four edges of the plot. Photos were taken of both planted and unplanted plots during a lower biomass season to establish a baseline of percent cover for each vegetation treatment. Using ImageJ, we minimized the reflectance in each photo and determined the percentage of green pixels in each photograph (Schneider et al. 2012). Percent green served as a means of separating living tissue from dead tissue and sediment, and acts as a proxy for percent cover in each plot.

\section{Salinity}

Salinity was measured via porewater sampling in November 2019. Using a sipper constructed with a long piece of $1 / 4$ inch tubing with small holes drilled in the end, the tubing was driven into the soil of each plot at least $20 \mathrm{~cm}$ deep. Using a syringe, porewater was pulled up through the tubing and collected in scintillation vials. Vials were left undisturbed for an hour to allow sediment to settle, and porewater salinity was measured with a refractometer. vegetation. 5 plots from each treatment were planted with 10 mangrove seedlings each, while the remaining 5 plots in each treatment were unplanted for use as control plots

\section{Tea Bag Index}

To measure in situ decomposition rates of SOM, we used the tea bag index in each of the 20 plant plots and 20 unplanted plots at GTM as outlined in Keuskamp et al. (2013) to compare how SOM decomposition rates of different community structures changed in response to the presence of mangrove seedlings. This index uses two types of commercially available Lipton tea bags with contrasting decomposability to construct a decomposition curve at one time point (Keuskamp et al. 2013). In each plot, we buried one green tea bag and one rooibos tea bag at a depth of $8 \mathrm{~cm}$ roughly $15 \mathrm{~cm}$ apart. Tea bags were removed after 3 months, after which they were washed, dried, and weighed to assess changes in mass due to decomposition. The first two sets of tea bags were removed and replaced at 3 months, though due to the COVID-19 pandemic the third set of tea bags were deployed for 6 months.

\section{Statistical Analysis}

To determine differences between mean mangrove mortality across treatments, we performed a repeated measures ANOVA with vegetation and time as factors. Differences in percent cover and salinity across vegetation treatments were determined using one-way ANOVAs. We used two separate 2-way ANOVAs to determine differences in both decomposition rate $(\mathrm{k})$ and stabilization factor $(\mathrm{S})$ between planted and unplanted plots and across all vegetation treatments. To find differences in means, we used Tukey's post hoc HSD tests for all analyses. All analyses were conducted in R version 3.1.2 (R Core Team 2019). 


\section{Results}

\section{Percent Cover}

Out of the three treatment types with vegetation, the mixed treatment plots had the greatest average percent cover $\left(\mathrm{F}_{2,27}=\right.$ $8.356, p=0.0015$, Fig. 2; Table 2). Average percent cover in Mixed plots was $20.9 \%$ greater than percent cover in B. maritima plots, and $37.4 \%$ greater than percent cover in S. alterniflora plots.

\section{Salinity}

Salinity differed across treatments $\left(\mathrm{F}_{3,34}=8.111, \mathrm{p}=\right.$ 0.00033, Table 2). Mean salinity in Mudflat plots (29.75 ppt) was significantly lower than all vegetated plots. Mixed plots had the highest average salinity of 34.30 ppt, followed by B. maritima dominated plots at 32.80 ppt and S. alterniflora dominated plots at $32.30 \mathrm{ppt}$ (Table 2).
Table 2 Average porewater salinity (ppt) in each vegetation treatment. Mud flat salinity was significantly lower than the rest of the treatments

\begin{tabular}{lll}
\hline Treatment & Mean salinity (ppt) & SD \\
\hline B. maritima & 32.80 & 1.686548 \\
S. alterniflora & 32.30 & 1.337494 \\
Mixed & 34.30 & 3.020302 \\
Mudflat & 29.75 & 1.035098 \\
\hline
\end{tabular}

\section{Decomposition}

Across the four distinct plant community structures in the decomposition experiment mangrove presence had no effect on decomposition rate $(\mathrm{k})$, though community structure had an effect $\left(\mathrm{F}_{3,26}=14.735, \mathrm{p}=8.36 \mathrm{e}-06\right.$, Table 3$)$. Mixed treatment plots had the highest average decomposition rate $(\mathrm{k}=0.0116)$, which was $47 \%$ greater compared to the lowest decomposition rate in Mudflat plots $(\mathrm{k}=0.007)$ (Fig. 3). Mangrove

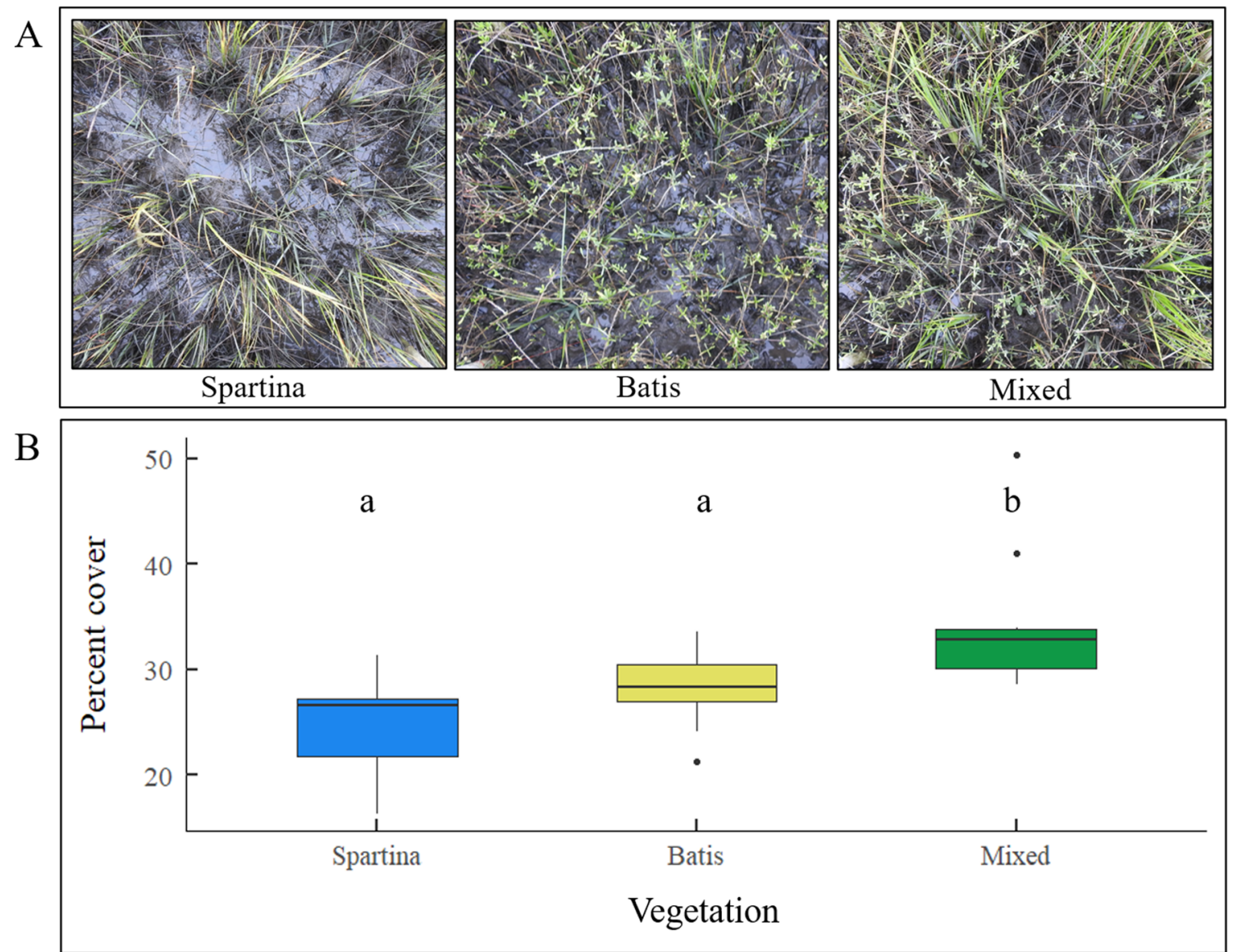

Fig. 2 (A) Representative images from each plant community composition treatment that contained vegetation; $S$. alterniflora, B. maritima, and a mixture of the two. Mudflat plots are not pictured, as percent cover was not measured in those plots due to complete lack of vegetation. (B) Percent cover by treatment in each of the plots (planted and unplanted combined). Mixed plots show a significantly greater percent cover than $S$. alterniflora and B. maritima, plots $\left(\mathrm{F}_{2,27}=8.356\right.$, $\mathrm{p}=0.0015$ ), whereas $S$. alterniflora and $B$. maritima, were not statistically different from each other. Error bars indicate standard error, letters indicate significance 
Table 3 2-way ANOVA tables for vegetation and mangrove presence by decomposition rate $(\mathrm{k})$ and stabilization factor $(\mathrm{S})$. Bold entries denote statistical significance

\begin{tabular}{lccrr}
\hline & Df & Sum Sq & F Value & P $(>\mathrm{F})$ \\
\hline Decomposition rate (k) & & & & \\
Vegetation & 3 & $6.654 \mathrm{e}-05$ & 14.735 & $\mathbf{< 0 . 0 0 1}$ \\
Mangrove & 1 & $2.720 \mathrm{e}-06$ & 1.805 & 0.191 \\
Vegetation:Mangrove & 3 & $1.2552-06$ & 0.834 & 0.488 \\
Stabilization factor (S) & & & & \\
Vegetation & 3 & 0.01171 & 2.732 & 0.0606 \\
Mangrove & 1 & 0.00151 & 1.060 & 0.3113 \\
Vegetation:Mangrove & 3 & 0.04430 & 0.832 & 0.4864 \\
\hline
\end{tabular}

presence had no effect on stabilization factor $(\mathrm{S})$, though vegetation treatment had a marginal effect $\left(\mathrm{F}_{3,31}=2.732, \mathrm{p}=\right.$ 0.0606 , Table 3). B. maritima plots showed the greatest $\mathrm{S}$ factor, followed by Mudflat and S. alterniflora plots. Mixed plots had the lowest average S factor of 0.0797 (Fig. 3).

\section{Mangrove Survivorship}

Mangrove seedling mortality was highest in Mudflat treatment plots, reaching $90 \%$ by the first measurement (May 2019), and $100 \%$ mortality by the second (August 2019) ( $\mathrm{p}=3.611 \mathrm{e}-08$, Fig. 4; Table 4). Similarly, mangrove seedling mortality was also high in the $S$. alterniflora treatment, reaching $68 \%$ by May and maxing out at $96 \%$ by August. Seeding mortality was lower in B. maritima plots, reaching $50 \%$ by May and increasing to $70 \%$ by the end of the experiment. Mixed treatment plots showed the lowest mortality overall, reaching $32 \%$ by May and $70 \%$ by the end of the experiment. At the end of the experiment, total

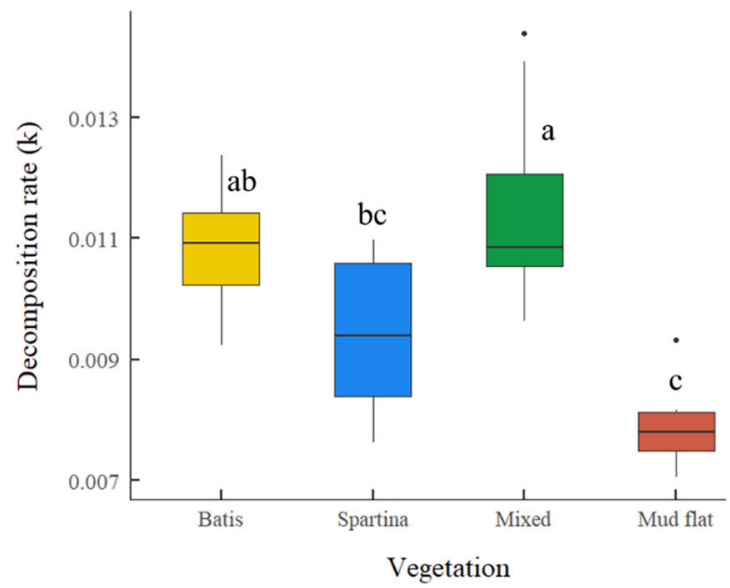

Fig. 3 Two way ANOVA found no effect of Mangrove presence on decomposition rate $(\mathrm{k})$, but Vegetation had a significant effect on $\mathrm{k}$ $(\mathrm{p}=8.36 \mathrm{e}-06)$. Mixed plots had the highest $\mathrm{k}$, while Mudflat plots had the lowest k. Two way ANOVA found no effect of Mangrove presence mortality in Mixed treatment plots was $42 \%$ lower than mangrove mortality in mud flat treatment plots (Table 4).

\section{Discussion}

We examined how marsh plant community structure and percent cover can affect mangrove survivorship and belowground decomposition in the mangrove-marsh ecotone of NE Florida. We hypothesized that (1) mangroves planted in plots with greater percentages of $B$. maritima would exhibit lower mortality rates; (2) mangroves would exhibit low mortality in plots with high plant percent cover; and (3) plots with planted mangroves would exhibit higher decomposition rates compared to paired plots without mangroves. We found some support for our first two hypotheses. Mangroves planted in Mixed plots where $B$. maritima was present in mixture with $S$. alterniflora had the highest mangrove survivorship and highest percent cover overall, though the B. maritima and $S$. alterniflora monoculture treatments did not differ significantly from each other in any capacity. Decomposition rates were also highest in Mixed plots, and on average decomposition rate in Mixed plots was $47 \%$ greater than average Mudflat decomposition rate, though we did not find any effect of mangrove presence on decomposition. Here we explore possible explanations for the patterns we observed.

One possible explanation for the differential mangrove survivorship across marsh vegetation could be due to variation in percent cover across vegetated treatments. Mangroves do not typically establish in areas devoid of vegetation which corroborates our finding of total mortality of mangrove seedlings in the Mudflat plots. This is unsurprising as mudflats can be harsh environments for establishing plants, including mangrove and other marsh species, due to extreme abiotic conditions such as high salinity, sulfide build-up, and hypoxia

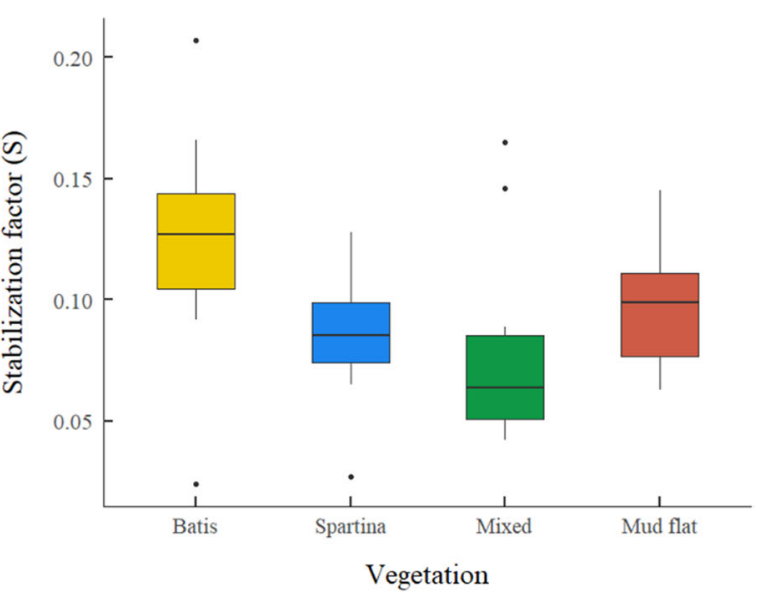

and no effect of Vegetation on stabilization factor (S). Lettersdenote significance, figure shows data from planted and unplanted plots as there was no significant difference between those groups 
Fig. 4 Repeated measures ANOVA on mortality of mangrove seedlings by vegetation over time. Mangrove mortality increase over time $(\mathrm{p}=1.839 \mathrm{e}$ $10)$ and by vegetation treatment $(\mathrm{p}=3.611 \mathrm{e}-08)$, but no interactive effects. Mixed and B. maritima plots were significantly greater in mangrove survival over time compared to $S$. alterniflora plots and Mudflat plots. Lsmeans used for a posthoc test

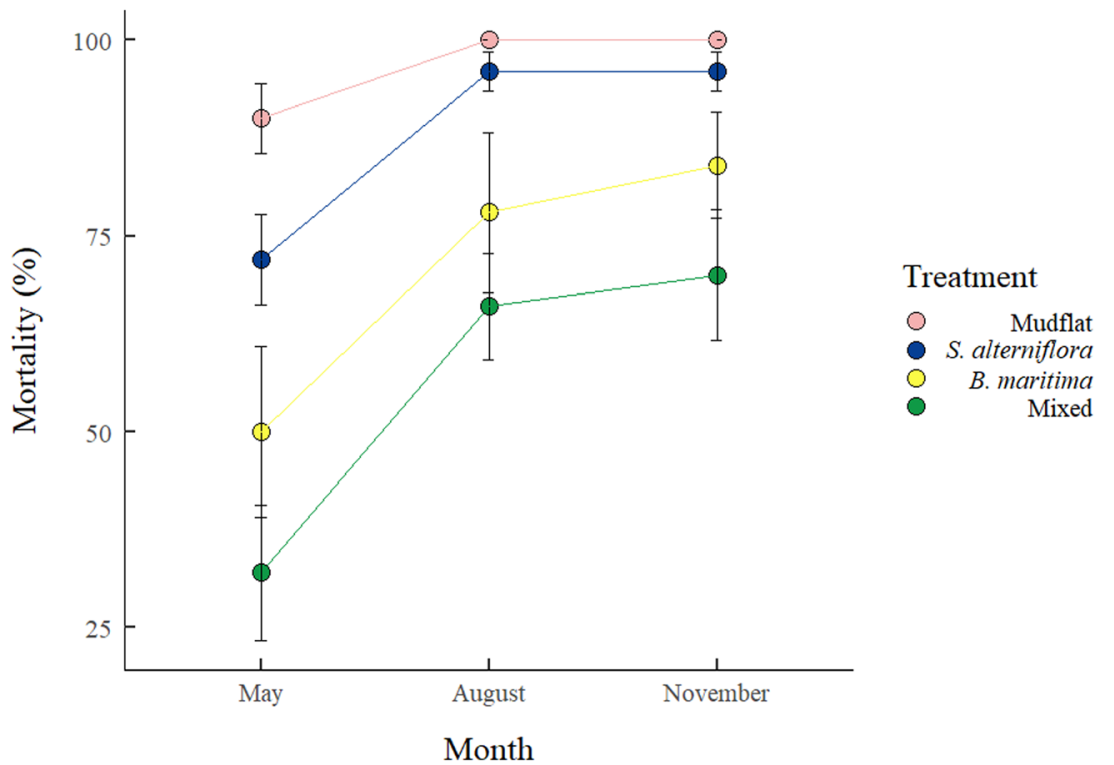

(Milbrandt and Tinsley 2006; Lewis 2009; Yando et al. 2016). Among the vegetated treatments, Mixed plots were $37.4 \%$ more dense in cover compared to S. alterniflora plots (Fig. 2), and mortality in Mixed plots was $42 \%$ lower compared to Mudflat plots (Fig. 4). The higher rates of mangrove survivorship we found in plots containing some percentage of $B$. maritima correlate positively with a higher total percent cover of vegetation (Fig. 5).

It is possible that the dense cover in Mixed and B. maritima plots provided more protection for mangrove seedlings compared to the sparse coverage in S. alterniflora plots and complete lack of cover in Mudflat plots. Seedlings at this stage (23 years old) are sensitive to temperature fluctuations (Pickens and Hester 2011), and temperature in patches of B. maritima have been found to be lower than areas without B. maritima, likely due to shading effects (Milbrandt and Tinsley 2006). In addition to shading effects, dense vegetation can slow tidal flow and minimize turbulence, allowing for entrapment of sediment particles and minimizing sediment deposition on leaves (reviewed by Cahoon et al. 2021). In Mudflat plots, the leaves of planted mangroves were covered in sediment at the second timepoint, which may have contributed to total mortality in the Mudflat treatment (Adgie, personal observation). Batis maritima also has less fibrous roots compared to

Table 4 Repeated measures ANOVA table of mangrove mortality by vegetation over time. Bold entries denote statistical significance

\begin{tabular}{llcc}
\hline Source & Df & Chi Sq & P (>Chi Sq) \\
\hline Vegetation & 3 & 37.4976 & $<\mathbf{0 . 0 0 1}$ \\
Time & 1 & 40.6305 & $<\mathbf{0 . 0 0 1}$ \\
Vegetation:Time & 3 & 6.7549 & 0.08014 \\
\hline
\end{tabular}

S. alterniflora, which may be able to break up the dense S. alterniflora root mat and provide more space belowground for mangroves to establish. We suggest that in mixed plots, the combination of B. maritima and S. alterniflora provides dense aboveground cover which acts as protection, while also providing more space belowground for mangrove seedlings to establish. Though we did not measure elevation explicitly in this study, small fluctuations in elevation may influence inundation period across treatments and therefore could influence mangrove survival, which we further explore below.

The zonation of vegetation in coastal salt marshes is largely dictated by physical stressors, namely tidal flooding, and this zonation can also contribute to seedling mortality (Pennings and Callaway (Pennings and Callaway 1992; Bertness and Hacker 1994). Spartina alterniflora has a higher flooding tolerance than the black mangrove, resulting in mangroves growing at higher elevations in comparison to S. alterniflora in many coastal ecosystems (Patterson and Mendelssohn 1991). Batis maritima tends to grow in the transitional area from the high marsh to the low marsh but cannot tolerate the same level of flooding as S. alterniflora. Though this study took place solely in the low marsh, subtle fluctuations in elevation may ultimately be the driver of plant zonation in this area. It is possible that the optimal elevation ranges for S. alterniflora and B. maritima overlap in an elevational range that may be most suitable for mangrove success. Subtle differences in elevation across vegetation types may therefore be a driver for mangrove survival (Rogers et al. 2014). Elevation differences also drive differences in timing and extent of flooding, which could impact soil oxygenation. The higher decomposition rates in Mixed plots we found may reflect less intense tidal flooding due to higher elevation, improving oxygen availability and subsequently promoting mangrove survival. Plants also contribute to increases in soil surface 

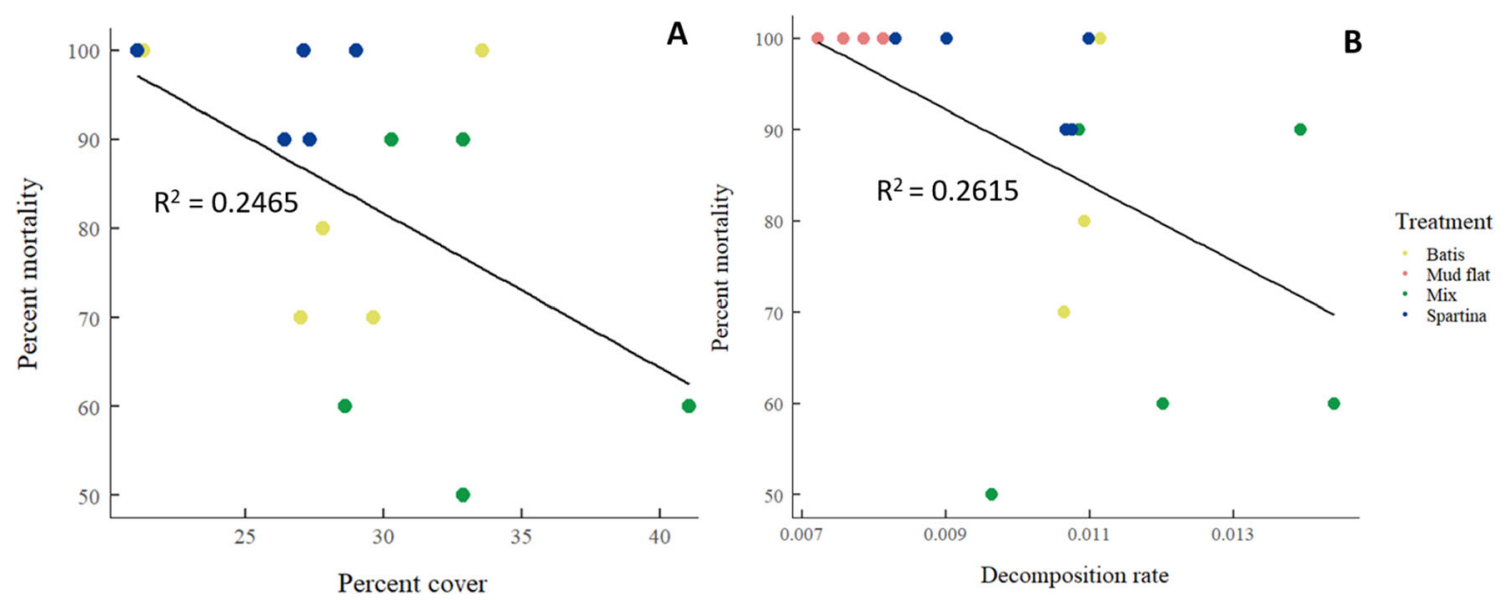

Fig. 5 A) Percent mortality of mangrove seedlings tends to decrease with increasing percent cover of treatment plots $\left(r^{2}=0.2465, p=0.0598\right)$. B $)$ Percent mortality of mangrove seedlings tends to decrease as decomposition rate increases $\left(r^{2}=0.2615, p=0.0359\right)$

elevation by trapping sediment particles and contributing to soil volume via root and rhizome production (Reviewed by Cahoon et al. 2021), but the exact contributions of individual marsh plant species to overall marsh elevation gain is not well understood. It is therefore possible that subtle differences in elevations across the low marsh could in part be an artifact of plant community structure and zonation and should be further studied.

Belowground parameters such as plant-soil feedbacks, nutrient availability, and oxygen delivery may also be a driver of differences in mangrove survivorship across treatments. As $S$. alterniflora can have allelopathic effects on surrounding vegetation (Wu et al. 2006; Chen et al. 2020) and $B$. maritima has been implicated as a facilitator of mangrove encroachment (Milbrandt and Tinsley 2006; TeutliHernandez et al. 2019) we were surprised to find that the Mixed treatment where $B$. maritima and $S$. alterniflora were present in equal proportion exhibited the highest mangrove survivorship. Recent studies on the effects of fertilization show that $A$. germinans takes advantage of increased $\mathrm{N}$ availability to accelerate growth, whereas $S$. alterniflora shows no comparable growth response in similar conditions (Simpson et al. 2013; Weaver and Armitage 2018, Macy et al. 2020). At a site close to ours, Dangremond and others (Dangremond et al. 2020) showed that $A$. germinans growth is $\mathrm{N}$ limited. $B$. maritima can increase concentrations of available soil $\mathrm{N}$ (Teutli-Hernandez et al. 2019), and thus higher survivorship of mangroves in plots with some percentage of $B$. maritima may be due to higher concentrations of available soil $\mathrm{N}$. Further, differences in root architecture between $B$. maritima and $S$. alterniflora may result in differences in root exudates and oxygen delivery across plant community types. We propose that synergistic effects of variation in aboveground cover with differences in belowground root-driven nutrient availability and oxygen delivery may explain differences in mangrove mortality across plant community types.
We found that marsh plant community composition impacted decomposition rates and marginally changed stabilization factor (Table 4). In addition to the highest survivorship of mangroves and highest percent cover, Mixed plots also showed the highest decomposition rates (Fig. 3; Table 4). Conversely, the Mudflat treatment had the lowest decomposition rate in addition to total mangrove mortality and no vegetation coverage. We suggest that differential decomposition rates are driven by plant root dynamics. SOM decomposition is a process regulated by soil microbial communities (Allison et al. 2013), and influenced by temperature, litter input, and soil oxygen levels (Couteaux et al. 1995; Zhou et al. 2017). Wetlands are particularly oxygen limited which allows for inordinate amounts of $\mathrm{C}$ stabilization, but climate-driven shifts in vegetation may result in changes in oxygen delivery to wetland soils (reviewed by Chapman et al. 2019). Rootmediated changes to the soil environment can provide soil microorganisms with oxygen or other substrates that alter microbial community structure (Noll et al. 2005; Lipson et al. 2015), implying that increased decomposition rates in Mixed plots may indicate the presence of more aerobic bacteria compared to the other vegetation treatments. Though only marginally significant, low stabilization factor in Mixed plots indicates that only a small amount of material was sequestered rather than decomposed (Seelen et al. 2019), indicating a more active and efficient microbial community in mixed soils. As mangrove soils typically contain more putatively aerobic bacteria as compared to marsh-dominated soils (Barreto et al. 2018), increased oxygen availability in Mixed plots which would benefit early life-stage mangroves that lack well-developed aerenchyma (Pezeshki et al. 1991). It is also possible that increased decomposition rates in Mixed plots is the result of increased biomass associated with high percent cover in Mixed plots. Increased root mass can increase oxygenation of the soil, thereby increasing decomposition rate. It is therefore difficult to determine whether high decomposition 
rates in Mixed plots was driven by increased diversity, species-specific effects, or simply an increase in root biomass. Though differences in vegetation can impact decomposition rates via leaf litter quality and plant morphology (McKee and Seneca 1982; Melillo et al. 1984), we cannot exactly tease apart the relationship between vegetation and decomposition in this study. However, we believe that the linkage between decomposition, salt marsh vegetation, and mangrove mortality is clear and it would be useful to further explore the drivers of this relationship in future studies.

Counter to our hypothesis that planting mangroves would increase decomposition, we found that mangrove planting had no influence on decomposition or stabilization factor (Fig. 4; Table 2). Adult mangroves have welldeveloped aerenchyma, which aids in oxygenation of their roots and may drive increased SOM decomposition in mangrove soils (Howes et al. 1986; Wigand et al. 1997; Perry and Mendhelsson 2009). However, this study used mangroves at the seedling stage which may not have welldeveloped enough oxygen-transporting systems to effect root oxygenation (Pezeshki et al. 1991). Furthermore, previous findings have shown that total soil respiration is highest in established mangroves compared to marshdominated or transitional areas (Simpson et al. 2019). Though mangrove encroachment can rapidly alter an abundance of ecosystem services, it may take anywhere from 3 years to a few decades of mangrove presence to influence SOM decomposition, if at all (Perry and Mendelssohn 2009; Osland et al. 2012; Henry and Twilley 2013; Doughty et al. 2016; Kelleway et al. 2016, Guo et al. 2017; Simpson et al. 2019). Out of 200 mangroves we planted, $120(60 \%)$ died within the first 3 months of our experiment, increasing to $84 \%$ by the end of the study. It is likely that the high mangrove mortality and short duration of this study combined with the age of planted mangroves and overall dominance of marsh plant species mitigated any mangrove-driven effects on decomposition due to lack of sufficient mangrove root biomass. Though relative mangrove loss has slowed in certain parts of the world over the past few years (Friess 2016; Feller et al. 2017; Freiss et al. 2020), nearly $2 \%$ of the world's mangrove coverage has been lost between 2000 and 2012 (Hailton and Casey 2016) largely due to deforestation and habitat conversion in the tropics (Valiela et al. 2001; Spalding et al. 2010). Continued conservation efforts have contributed to the slow of mangrove decline (Freiss 2016, Freiss et al. 2020), though many attempts to restore large areas of mangrove wetlands via planting tend to fail due to a combination of inappropriate planning and lack of postplanting care (Lewis 2009; Kodikara et al. 2017). Though establishing appropriate hydrology is key for mangrove restoration (Lewis 2009), restoration efforts have shown some success in also promoting mangrove establishment via promotion of foundational marsh species (Yando et al. 2019). Our study further supports the importance of established marsh species for mangrove success and suggests that areas of increased marsh species diversity may aid in successful mangrove restoration efforts.

Despite continued efforts to understand the global poleward encroachment of mangroves, little is understood about how existing salt marsh plant community structures may influence both continued encroachment and future mangrove restoration projects and management. Our results show that marsh plant community composition can influence the survival of mangrove seedlings, indicating that community level dynamics and plant root-driven effects may play an integral role in the continued encroachment of mangroves into salt marsh. Our study also shows that high percent cover and high decomposition rates in mixed marsh plots corresponded to increased mangrove survivorship, though the exact drivers of this relationship remains unclear. Percent cover and decomposition therefore may be developed as low-cost, simple metrics for understanding continued mangrove encroachment and for determining site suitability for mangrove restoration projects. Studies examining how salt marsh plant community composition and species zonation may relate to marsh elevation would be a valuable next step in understanding how encroaching mangroves are impacted by marsh plant community structure. Ultimately, it is important to consider the established salt marsh community structure and potential plant-root driven belowground effects as factors in understanding mangrove encroachment in a future warmer world with higher sea levels.

Acknowledgements We acknowledge Emily Geoghegan, Charles Hyde, Nicole Spanier, Gabriela Canas, Claire Fell, Emma Guilbault, Philip Yang, and Damir Creecy who helped perform field and lab work. J. Adam Langley and Ilka C. Feller provided useful feedback on this manuscript.

Authors' Contributions All authors contributed to the study conception and design. Material preparation, data collection and analysis were performed by TE Adgie as partial fulfillment of requirements for the degree of Master of Science in Biology, as advised by SK Chapman. The first draft of the manuscript was written by TE Adgie and all authors commented on previous versions of the manuscript. All authors read and approved the final manuscript.

Funding This work was funded by National Science Foundation, DEB 1655659.

Data Availability The datasets generated during and/or analyzed during the current study are available from the corresponding author on reasonable request.

Code Availability The code generated to analyze datasets during this current study are available from the corresponding author on reasonable request. 


\section{Declarations}

\section{Ethics Approval N/A.}

Consent to Participate N/A.

Consent for Publication N/A.

\section{References}

Allen WJ, Meyerson LA, Flick AJ, Cronin JT (2018) Intraspecific variation in indirect plant soil feedbacks influences a wetland plant invasion. Ecology 99(6): 1430-1440

Allison SD, Lu Y, Weihe C, Goulden ML, Martiny AC, Treseder KK, Martiny JB (2013) Microbial abundance and composition influence litter decomposition response to environmental change. Ecology 94: 714-772

Barreto CR, Morrissey EM, Wykoff D, Chapman SK (2018) Cooccurring mangroves and salt marshes differ in microbial community composition. Wetlands 38:497-508

Bertness MD, Callaway R (1994) Positive interactions in communities. Trends in Ecology \& Evolution 9:191-193

Bertness MD, Hacker SD (1994) Physical stress and positive associations in marsh plants. The American Naturalist 144(3):363-372

Cahoon DR, McKee KL, Morris JT (2021) How plants influence resilience of salt marsh and mangrove wetlands to sea-level rise. Estuar Coasts 44:883-898. https://doi.org/10.1007/s12237-020-00834-w

Casalini AI, Bisigato AJ (2018) Stress-gradient hypothesis and plant distribution along ecotonal gradients. Austral Ecology 43:807-816

Cavanaugh K, Kellner JR, Forde AJ, Gruner DS, Parker JD, Rodriguez W, Feller IC (2014) Poleward expansion of mangroves is a threshold response to decreased frequency of extreme cold events. Proc Natl Acad Sci 111:723-727

Cavanaugh KC, Dangremond EM, Doughty CL, Williams AP, Parker JD, Hayes MA, Rodriguez W, Feller IC (2019) Climate-driven regime shifts in a mangrove-salt marsh ecotone over the past 250 years. PNAS 116(43):21602-21608. https://doi.org/10.1073/pnas. 1902181116

Chapman SK, Hayes MA, Kelly B, Langley JA (2019) Exploring the oxygen sensitivity of wetland soil carbon mineralization. Biol Lett 15:20180407. https://doi.org/10.1098/rsbl.2018.0407

Chapman SK, Feller IC, Canas G, Hayes MA, Dix N, Hester M, Morris J, Langley JA (2021) Mangrove growth response to experimental warming is greatest near the range limit in northeast Florida. Ecology 102(6):e03320. https://doi.org/10.1002/ecy.3320

Chen E, Blaze JA, Smith RS, Peng S, Byers JE (2020) Freeze tolerance of poleward spreading mangrove species weakened by soil properties of resident salt marsh competitor. Journal of Ecology 00:1-13

Coldren GA, Barreto CR, Wykoff DD, Morrissey EM, Langley JA, Feller IC, Chapman SK (2016) Chronic warming stimulates growth of marsh grasses more than mangroves in a coastal wetland ecotone. Ecology 97(11):3197-3175

Comeaux RS, Allison M, Bianchi TS (2012) Mangrove expansion in the Gulf of Mexico with climate change: Implications for wetland health and resistance to rising sea levels. Estuar Coast Shelf Sci 96:81-95

Cook-Patton SC, Lehmann M, Parker JD (2015) Convergence of three mangrove species towards freeze-tolerant phenotypes at an expanding range edge. Functional Ecology 29:1332-1340

Corbin JD, D'Antonio DM (2012) Gone but not forgotten? Invasive plants' legacies on community and ecosystem properties. Invasive Plant Science and Management 5:117-124

Couteaux MM, Bottner P, Berg B (1995) Litter decomposition, climate and liter quality. Trends in Ecology and Evolution 10(2):63-66
Dangremond EM, Simpson LT, Osborne TZ, Feller IC (2020) Nitrogen enrichment accelerates mangrove range expansion in the temperatetropical ecotone. Ecosystems 23(4):703-714

Delgado, Hensel PF, Jiménez JA, Day JW (2001) The importance of propagule establishment and physical factors in mangrove distributional patterns in a Costa Rican estuary. Aquatic Botany 71:157-178

Doughty CL, Langley JA, Walker WS, Feller IC, Schaub R, Chapman SK (2016) Mangrove range expansion rapidly increases coastal wetland carbon storage. Estuaries and Coasts 39:385-396

Durango J, Satyanarayana B, Zhang J, Wang J, Chen M, Bogaert J, Koedam N, Dahdouh-Guebas F (2013) Vegetation structure at Zhanjiang Mangrove National Nature Reserve (ZMNNR), P.R. China: comparison between original and non-original trees using ground-truth, remote sensing and GIS techniques. Available at: www.vliz.be/imisdocs/publications/232700.pdfwww.vliz.be/ imisdocs/publications/232700.pdf

Ellison AM, Bank MS, Clinton BD et al (2005) Loss of foundation species: consequences for the structure and dynamics of forested ecosystems. Frontiers in Ecology and the Environment 3:479-486

Emery NC, Ewanchuk PJ, Bertness MD (2001) Competition and saltmarsh plant zonation: stress tolerators may be dominant competitors. Ecology 82:2471-2485

Feller IC, Friess DA, Krauss KW, Lewis RR III (2017) The state of the world's mangroves in the 21 st century under climate change. Hydrobiologia 803:1-12. https://doi.org/10.1007/s107500173331-z

Friess DA (2016) Turning the tide on mangrove loss. Marine Pollution Bulletin 109:673-675

Friess DA, Yando ES, Abuchahla GMO et al (2020) Mangroves give cause for conservation optimism, for now. Current Biology 30: R135-R158

Fujii S, Cornelissen JHC, Berg MP, Mori AS (2018) Tree leaf and root traits mediate soil faunal contribution to litter decomposition across an elevational gradient. Functional Ecology 32(3):840-852

Godoy MDP, Lacerda LD (2015) Mangroves response to climate change: a review of recent findings on mangrove extension and distribution. Anais da Academia Brasileira de Ciências 87(2):651-667

Grove S, Parker IM, Haubensak KA (2015) Persistence of a soil legacy following removal of a nitrogen-fixing invader. Biological Invasions 17:2621-2631

Guo H, Weaver C, Charles SP, Whitt A, Dastidar S, D'Odorico P, Fuentes JD, Kominoski JS, Armitage AR, Pennings SC (2017) Coastal regime shifts: rapid responses of coastal wetlands to changes in mangrove cover. Ecology 98:762-772

Hailton SE, Casey D (2016) Creation of a high spatio-temporal resolution global database of continuous mangrove forest cover for the 21st century (CGMFC-21). Global Ecology and Biogeography 25:729738

Henry KM, Twilley RR (2013) Soil development in a coastal Louisiana wetland during a climate-induced vegetation shift from salt marsh to mangrove. Journal of Coastal Research 29(6):1273-1283

HilleRisLambers J, Harsch MA, Ettinger AK, Ford KR, Theobald EJ (2013) How will biotic interactions influence climate changeinduced range shifts? Annals N Y Acad Sci 1297:112-125. https:// doi.org/10.1111/nyas. 12182

Howes BL, Dacey JWH, Goehringer DD (1986) Factors controlling the growth form of Spartina alterniflora: Feedbacks between aboveground production, sediment oxidation, nitrogen, and salinity. Journal of Ecology 74:881-898

Kangas PC, Lugo AE (1990) The distribution of mangroves and saltmarsh in Florida. Tropical Ecology 31:32-39

Kelleway JJ, Saintilan N, Macreadie PI, Skilbeck CG, Zawadzki A, Ralph PJ (2016) Seventy years of continuous encroachment substantially increases 'blue carbon' capacity as mangroves replace intertidal salt marshes. Glob Chang Biol 22:1097-1109

Keuskamp JA, Dingemans BJJ, Lehtinen T, Sarneel JM, Hefting MM (2013) Tea Bag Index: a novel approach to collect uniform 
decomposition data across ecosystems. Methods Ecol Evol 4:1070 1075. https://doi.org/10.1111/2041-210X.12097

Kirwan ML, Blum LK (2011) Enhanced decomposition offsets enhanced productivity and soil carbon accumulation in coastal wetlands responding to climate change. Biogeosciences 8:987-993

Kodikara KAS, Mukherjee N, Jayatissa LP, Dahdouh-Guebas F, Koedam N (2017) Have mangrove restoration projects worked? An in-depth study in Sri Lanka. Restoration Ecology 25(5):705-716

Krauss KW, From AS, Doyle TW, Doyle TJ, Barry MJ (2011) Sea-level rise and landscape change influence mangrove encroachment onto marsh in the Ten Thousand Islands region of Florida, USA. Journal of Coastal Conservation 15:629-638

Kulmatiski A, Beard KH, Stevens JR, Cobbold SM (2008) Plant-soil feedbacks: a meta analytical review. Ecology Letters 11:980-992

Lewis RR (2009) Methods and criteria for successful mangrove forest restoration. In: GME P, Wolanski E, Cahoon DR, Brinson MM (eds) Coastal Wetlands: An Integrated Ecosystem Approach. Elsevier Press, Amsterdam, pp 787-800

Lipson DA, Raab TK, Parker M, Kelley ST, Brislawn CJ, Jansson J (2015) Changes in microbial communities along redox gradients in polygonized Arctic wet tundra soils. Environmental Microbiology Reports 7(4):649-657

Lovelock CE, Feller IC, Ellis J, Schwarz AM, Hancock N, Nichols P, Sorrell B (2007) Mangrove growth in New Zealand estuaries: the role of nutrient enrichment at sites with contrasting rates of sedimentation. Oecologia 153:633-641

Macy A, Osland MJ, Cherry JA, Cebrian J (2020) Changes in ecosystem nitrogen and carbon allocation with black mangrove (Avicennia germinans) encroachment into Spartina alterniflora salt marsh. Ecosystems 1-17. https://doi.org/10.1007/s10021-02000565-w

Malkinson D, Tielbörger K (2010) What does the stress gradient hypothesis predict? Resolving the discrepancies. Oikos 119:1546-1552

Maricle BR, Lee RW (2002) Aerenchyma development and oxygen transport in the estuarine cordgrasses Spartina alterniflora and S. anglica. Aquatic Biology 74(2):106 120

McKee K, Seneca E (1982) The influence of morphology in determining the decomposition of two salt marsh macrophytes. Estuaries 5:302309

Melillo JM, Naiman RJ, Aber JD, Linkins AE (1984) Factors controlling mass loss and Nitrogen dynamics of plant litter in decaying streams. Bull Mar Sci 35(3):341-356

Milbrandt EC, Tinsley MN (2006) The role of saltwort (Batis maritima L.) in regeneration of degraded mangrove forests. Hydrobiologia 568:369-377

Mueller P, Scille-Beers LM, Mozdzer TJ et al (2018) Global-change effects on early stage decomposition processes in tidal wetlandsimplications from a global survey using standardized litter. Biogeosciences 15:3189-3202

Noll M, Matthies D, Frenzel P, Derakshani M, Liesack W (2005) Succession of bacterial community structure and diversity in a paddy soil oxygen gradient. EnvironmentalMicrobiology 7(3):382-395

Osland MJ, Spivak AC, Nestlerode JA, Lessman JM, Almario AE, Heitmuller PT et al (2012) Ecosystem development after mangrove wetland creation: plant-soil change across a 20 year chronosequence. Ecosystems 15:848-866

Osland MJ, Enwright N, Day RH, Doyle TW (2013) Winter climate change and coastal wetland foundation species: salt marshes vs. mangrove forests in the southeastern United States. Glob Chang Biol 19:1482-1494

Patterson CS, Mendelssohn IA (1991) A comparison of physicochemical variables across plant zones in a mangal/salt marsh community in Louisiana. Wetlands 11:139 161

Patterson CS, McKee K, Mendelssohn IA (1997) Effects of tidal inundation and predation on Avicennia germinans seedling establishment and survival in a sub-tropical mangal/salt marsh community. Mangroves and Salt Marshes 1:103-111
Pennings SC, Callaway RM (1992) Salt marsh plant zonation: the relative importance of competition and physical factors. Ecology 73(2):681690

Perry CL, Mendelssohn IA (2009) Ecosystem effects of expanding populations of Avicennia germinans in a Louisiana Salt Marsh. Wetlands 29:396-406

Pezeshki SR, Matthews SW, Delaune RD (1991) Root cortex structure and metabolic responses of Spartina patens to soil redox conditions. Environ Exp Bot 31:91-97

Pickens CN, Hester MW (2011) Temperature tolerance of early life history stages of black mangrove Avicennia germinans: Implications for range expansion. Estuaries and Coasts 34:824-830

Pickens CN, Sloey TM, Hester MW (2019) Influence of salt marsh canopy on black mangrove (Avicennia germinans) survival and establishment at its northern latitudinal limit. Hydrobiologia 826:195208

Rabinowitz D (1978) Dispersal properties of mangroves propagules. Biotropica 10:47 57

R Core Team (2019) R: A language and environment for statistical computing. R Foundation for Statistical Computing, Vienna, Austria. http://www.R-project.org/

Rietl AJ, Overlander ME, Nyman AJ, Jackson CR (2016) Microbial community composition and extracellular enzyme activities associated with Juncus roemerianus and Spartina alterniflora vegetated sediments in Louisiana Saltmarshes. Microbial Ecology 71:290 303

Risser PG (1995) The status of the science examining ecotones. Bioscience 45:318-325

Rogers K, Saintilan N, Woodroffe CD (2014) Surface elevation change and vegetation distribution dynamics in a subtropical coastal wetland: implications for coastal wetland response to climate change. Estuar Coast Shelf Sci 149:46-56

Saintilan N, Wilson NC, Rogers K, Rajkaran A, Krauss KW (2014) Mangrove expansion and salt marsh decline at mangrove poleward limits. Global Change Biology 20:147-157

Schneider CA, Rasband WS, Eliceiri KW (2012) NIH Image to ImageJ: 25 years of image analysis. Nat Methods 9:671-675

Seelen LMS, Flaim G, Keuskamp J, Teurlincx S, Font RA, Tolunay D, Frankova M, Sumberova K, Temponeras M, Lenhardt M, Jennings E, de Senerpont Domis LN (2019) An affordable and reliable assessment of aquatic decomposition: Tailoring the Tea Bag Index to surface waters. Water Research 151:31-43

Simpson LT, Feller IC, Chapman SK (2013) Effects of competition and nutrient enrichment on Avicennia germinans in the salt marshmangrove ecotone. Aquatic Biology 104:55-59

Simpson LT, Osborne TZ, Feller IC (2019) Wetland soil CO2 efflux along a latitudinal gradient of spatial and temporal complexity. Estuar Coasts 42:45-54

Sousa WP, Kennedy PG, Mitchell BJ (2003) Propagule size and predispersal damage by insects affect establishment and early growth of mangrove seedlings. Oecologia 135:564-575

Spalding MD, Kainuma M, Collins L (2010) World atlas of mangroves. Earthscan, London

Swales A, Bentley SJ, Lovelock CE (2015) Mangrove-forest evolution in a sediment-rich estuarine system: opportunists or agents of geomorphic change? Earth SurfaceProcesses and Landforms 40:1672-1687

Teutli-Hernández C, Herrera-Silveira JA, Comín FA, López MM (2019) Nurse species could facilitate the recruitment of mangrove seedlings after hydrological rehabilitation. Ecol Eng 130:263-270. https://doi. org/10.1016/j.ecoleng.2017.07.030

Tomlinson PB (1986) The botany of mangroves. Cambridge University Press, New York

Valiela I, Bowen JL, York JK (2001) Mangrove forests: one of the world's threatened major tropical environments. Bioscience 51: $807-815$

Weaver CA, Arimitage AR (2018) Nutrient enrichment shifts mangrove height distribution: Implications for coastal woody encroachment. 
PLoS One 13(3):e0193617. https://doi.org/10.1371/journal.pone. 0193617

Whigham DF, Michael C, Feller IC, Rodriguez W, King RS (2009) Ecological characteristics of Batis maritima in Florida and Belize. Proceedings of the Smithsonian Marine Science Symposium (491500)

Wigand C, Stevenson JC, Cornwel JC (1997) Effects of different submersed macrophytes on sediment biogeochemistry. Aquatic Botany $56: 233-244$

Wolf AA, Drake BG, Erickson JE, Megonigal JP (2007) An oxygenmediated positive feedback between elevated carbon dioxide and soil organic matter decomposition in a simulated anaerobic wetland. Global Change Biology 13:2036-2044

Wu JR, Chen ZQ, Peng SL (2006) Allelopathic potential of invasive weeds: Alternanthera philoxeroide, Ipomoea cairica and Spartina alterniflora. Allelopathy Journal 17:279 285
Yando ES, Osland MJ, Willis JM, Day RH, Krauss KW, Hester MW (2016) Salt marsh mangrove ecotones: using structural gradients to investigate the effects of woody plant encroachment on plant-soil interactions and ecosystem carbon pools. Journal of Ecology 104(4): $1020-1031$

Yando ES, Osland MJ, Jones SF, Hester MW (2019) Jump-starting coastal wetland restoration: a comparison of marsh and mangrove foundation species. Restoration Ecology 27(5):1145-1154

Zhou L, Li H, Shen H, Xu Y, Wang Y, Xing A, Fang J (2017) Shrubencroachment induced alterations in input chemistry and soil microbial community affect topsoil organic carbon in an Inner Mongolian grassland. Biogeochemistry 136:311-324

Publisher's Note Springer Nature remains neutral with regard to jurisdictional claims in published maps and institutional affiliations. 